\title{
PROBLEMS OF A SUSTAINABLE MANAGEMENT VALUE SYSTEM IN EASTERN EUROPE
}

Sustainable corporate responsibility is possible only on the basis of a sustainable value system that becomes part of an educational concept. In this regard a very inspirational book was written by Prof. Hans Küng from the University of Tübingen; it has the title: "Anständig wirtschaften" (2010) and the subtitle: "Warum Ökonomie Moral braucht?" (Decent management - Why does economics need morality?). Although the author is not an economist, banker, manager, or even an entrepreneur, his inspirational contribution is based on the urgency of the current crisis which consistently has consequences for the globalization process in businesses.

\section{Global challenges of the economic environment}

The starting point for the current challenges is the economic environment: above all, it is the phenomenon of globalization and the known turbulences (financial, political, ecological, sociological and criminal). The space which the manager should be able to manage and control is still more complex, causing increasing risk and unpredictability. The crisis of managerial modernism is related to the unidimensionality of the modernistic image of our world and of man; and it is related to our narrow understanding of economics and, of course, with the current focus within economic education. In order to avoid the deepening of moral fatigue and an increase in global skepticism or even of chaotic phenomena, it is essential to give consideration to these challenges.

\section{Causes of the one-sided orientation of education and change paradigm}

For a comprehensive understanding of the current state of the economic environment, management education needs to gain an understanding of history, of what is causing the one-sided orientation of education and what will bring about an understanding of potential solutions.

The development of the science of economics was influenced by Cartesian dualism (Kohak 1993) of the mechanical image of the world and of man, the later unilateral emphasis on rationalism, empiricism and last but not least on materialism. Economics was divorced from philosophy and the overall concept of values resulting in the emphasis on profit by Czech Business Law. East European society is becoming a part of economization. A man (manager and also consumer) is reduced to „homo economicus“" (Sedlacek, 2011), sometimes to a „bag of genes“ (Dawkins, 1976), or to a ,wet computer" (Pinker, 1997). The whole of society is reduced to a marketplace and the wealth of life to ,consumer hedonism" (Hosek, 2012). The crisis of modernity has revealed the limits of existing approaches and calls for a paradigm change. If the holistic view of the world and of man is to be established once again, it is necessary to replace the unilateral accents of modernity with the overall post-modern outlook on the world and economics on the basis of complex values. „Fragmentariness of science“ (Bohm, 2010) and shortterm, superficial pragmatism must be replaced by a universal value system. This aim has always served university education (universal view of science), with a long-term perspective beyond just one generation and its own regional framework. It is therefore understandable that the global market challenge needs a „global economic ethos“ (Küng, 2010: 304).

\section{References}

Küng, H. (2010). Anständig wirtschaften. München: Piper.

Hošek, P. (2012). A bohové se vraceji. Prague: Mlýn.

Kohák, E. (1993). Člověk, dobro a zlo. O smyslu života v zrcadle dějin. Prague: Ježek.

Pinker, S. (1997). How the minds works. London: Penguin Group.

Dawking, R. (1976). The Selfish Gene. Oxford: Oxford University Press.

Sedlacek, T. (2011). Economics of good and evil, Oxford: Oxford University Press.

Bohm, D. (1986). Fragmentierung und Ganzheit, in Physik und Transzendenz, ed. Dürr, H.-P., Bern: Scherz Verlag.

Author

Mgr. Dušan Kučera, MBA International School of Business and Management Faculty of Business Administration University of Economic, Prague Nám. W. Churchilla, 4, 13067 Praha 3 dusan.kucera@vse.cz 